\title{
膜体構造物における衝撃張力の発生メカニズムに関する 基礎的研究
}

\section{1. まえがき}

近年，オイルフェンスや污濁防止膜が，波浪条件の厳 しい海域で使用されることが多くなるとともに，曳航 ケーブルや係留策等が破断する事故が発生し，これら海 洋膜体構造物の設計法の見直しが求められている.青木 ら（1998）がすでに指摘しているように，これまでは， フレキシブルな膜体構造物の設計に対しても剛な構造物 の設計法を援用してきたため,これらの構造物は多くの 場合過大な設計になっていることが多い.しかしながら， オイルフェンスや垂下式污濁防止膜のように緩係留され た膜体構造物については，場合によっては過小設計と なっていることも考えられる. 実際, 波・流れ中でオイ ルフェンス等の張力測定実験を行うと，膜体が驰緩した 状態から波の作用により緊張する際に非常に大きな張力 が衝撃的に発生し(椹木ら，1990；田端ら，1999)，これ が設計上の限界值を与える場合が多い。これはフレキシ ブルな膜体構造物に特有の現象であり, 剛な構造物とし て取り扱う従来設計法ではこのような衝撃力は考慮でき ない。

椹木ら（1991）および Sawaragi et al.（1992）は，衝 撃張力を付加質量の考えをもとにモデル化しているが, 対象とした構造形式が複雑であったため，モデルの検証 が十分行われていない．またこのモデルは数值計算を含 むため，あまり実用的ではない。一方，田端ら（1999） は, 垂下式污濁防止膜について, 実際の展張形式で実験 を行い，衝撃張力を考慮した簡便な設計法を提案してい るが，構造形式が変わった場合に実験定数をどのように 決定するかが問題であろう。特に, 拘束力の強いボトム テンション形式のオイルフェンスや，膜下部を係留する ような污濁防止膜については,さらに検討が必要である. このように, 衝撃張力については, 構造形式や外力条件 によって特性の違いや結果のばらつきが大きく，定量的 な評価が難しいだけでなく，その発生メカニズムがはっ きりしないために，モデル化しにくいといった問題点が ある。できるだけ簡便で実用的な設計法を確立するため

\footnotetext{
${ }^{*}$ 正会員 工博 豊橋技術科学大学助教授 建設工学系
}

** 工修 滋賀県
青木 伸 一**岡 野 聡**

には，ある程度思いきったモデル化が必要ではあるが， 物理現象に対する理解を深めておくことがまず重要であ ろう. 本研究は, 流れの中を流れとともに移動する物体 (剛体および膜体)がその運動を係留策によって急に阻止 されたときに生じる流体力について，極めて単純化した 模型実験でその特徴を明らかにするとともに，簡単な数 学モデルを用いて衝撃張力の発生メカニズムとその特性 について検討するものである.

\section{2. 水理模型実験}

\section{（1）実験装置および方法}

模型実験は，一椂流を発生させることのできる小型回 流水槽（パーソナルタンク，西日本流体技研製）を用い て行った. 回流水槽には, 幅 $30 \mathrm{~cm}$, 深さ $20 \mathrm{~cm}$ の開水路 部分が $60 \mathrm{~cm}$ あり，インバーターによって流量を変化さ せることができる.この開水路部の上流端部に, 図一1に 示すように, 張力計 (SSK 社製) を介して1本の係留策 を取り付け，係留策の先端に凩状に抵抗体（アルミ平板 あるいは透水性の小さな化学繊維製の薄布）を取り付け た。な扔アルミ平板については，水中重量がほぼゼロと なるように，上部に発砲スチロールの小さなフロートを 付けた。係留策をたるませた状態で水面上に抵抗体を持 ち上げた後，一様流中に落とし込むと，抵抗体は流れに よって押し流され，係留策が緊張して静止する．実験で は, この一連の操作を, 各実験ケースについて 5 回程度 繰り返し行い,この間の係留策の張力を, サンプリング 周波数 $800 \mathrm{~Hz}$ でパソコンに記録した。

\section{(2) 実験条件}

アルミ平板（厚さ $0.5 \mathrm{~mm}$ ) については， 1 辺 $5 \mathrm{~cm}$ お

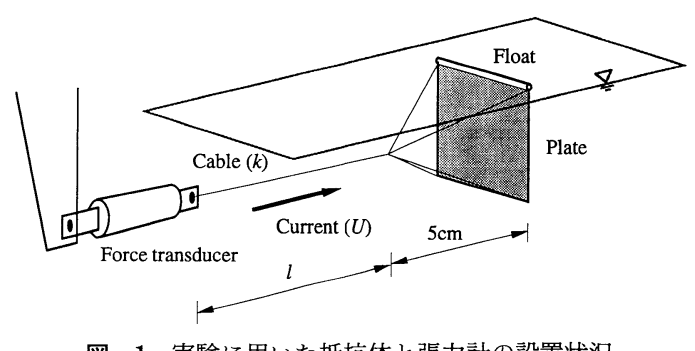

図一1 実験に用いた抵抗体と張力計の設置状況 
よび $7 \mathrm{~cm}$ の 2 種類の正方形板および $5 \mathrm{~cm} \times 10 \mathrm{~cm}$ （横 長）の長方形板を, 薄布（厚さ $0.064 \mathrm{~mm}$ ）については, 1 辺 $5 \mathrm{~cm}$ と $7 \mathrm{~cm}$ の 2 種類の正方形のものを用いた. 流 速は, $20 \sim 60 \mathrm{~cm} / \mathrm{s}$ の範囲で数種類変化させた. また, 係 留策長 $(15 \mathrm{~cm}$ と $20 \mathrm{~cm})$, 係留策の径および材質 (ナイ ロン製の釣糸およびゴムひも）を変化させることによっ て，係留策のバネ定数を数種類変化させた。 また，抵抗 体を落とし込む位置や係留策の設置深さを変えた実験も 比較のために行った.

\section{3. 実験 結 果}

\section{（1） 張力の時系列特性}

図一2 は，2 種類の異なる流速に対する張力の時系列 を，アルミ平板と薄布（以下単に「板」および「膜」と 呼ぶ）のケースで比較して示したものである。まず，板 については, 係留策が緊張した瞬間から $0.1 \mathrm{~s}$ 程度の間 に大きな張力が発生し, その後一定値に落ち着いている. 張力の最大值は, 流速が大きいほど大きくなっている. 一方, 膜については, 流速が大きい場合には衝撃的な張 力を示すが，その大きさは板に比べてかなり小さい.ま た流速が小さくなると, 衝撃的なピークは見られなく なっている。

図一3 は係留策のバネ定数の違いによる影響をみたも のである.小さなバネ定数，すなわち係留策が伸びやす くなると張力のピーク值は減少しバネ定数が 2 桁程度小 さなゴムひもでは衝撃的なピークは消えている.ただし， 定常力はほほ同一である.

図-4 は, 板のケースについて, 板の形状を変化させた 場合 $(7 \times 7$ と $5 \times 10)$ の張力を比較したものである.ただ し，板の面積はほぼ同一である. 図より，喫水深の大き な $7 \mathrm{~cm} \times 7 \mathrm{~cm}$ の板では, 張力のピーク值はやや大きく なり, 逆に定常力はやや小さくなっているが, 大きな違 いはみられない。

\section{（2）衝撃力と定常力}

図一2〜4では, 張力の時系列からその特性を定性的に 見た.ここでは, 張力の代表値として, 張力が最大值を 示した後に現われるほぼ定常な張力（時間平均值として 定義, 以下「定常力」と呼ぶ), および最大值から定常力 を差し引いたもの（以下「衝撃力」と呼ぶ）を取り上げ てそれらの特性を論じる. なお, 定常力については, 通 常の一様流中での抗力としてとらえられる.

図一5 は, 板のケースについて, 張力の代表値と流速の 関係を示したものである.これより, 衝撃力は流速の 1 乗に, 定常力は流速の 2 乗に比例して変化することがわ かる.また，板のサイズによる違いをみると，衝撃力と 定常力ではその比率が異なり，板面積が 2 倍になること により,衝撃力は約 3.1 倍, 定常力は約 2.5 倍になってい
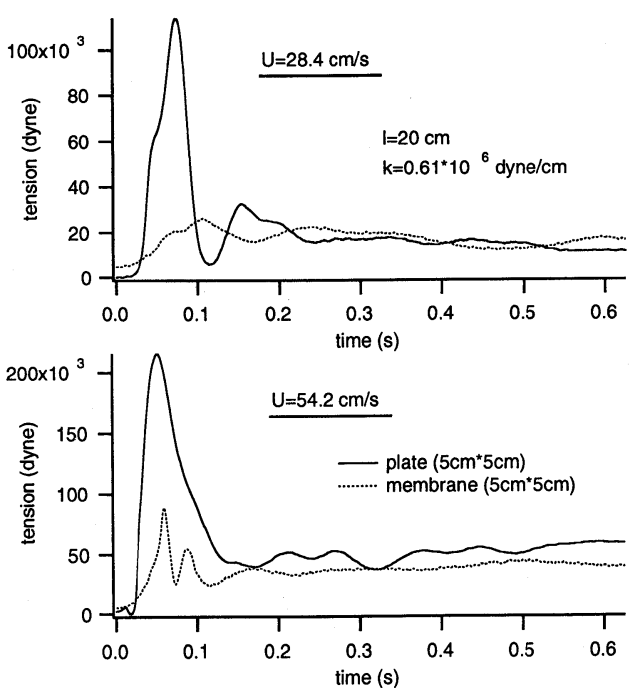

図-2 張力の時系列（流速および板と膜の違い）

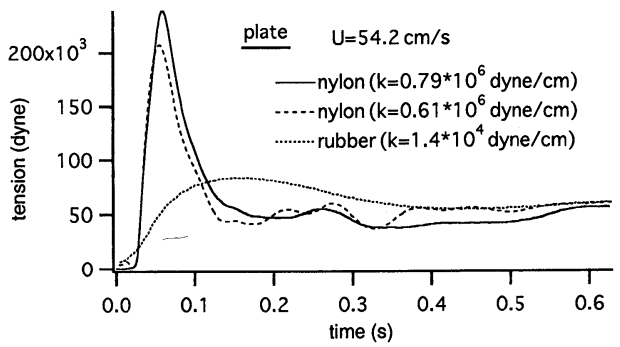

図一3 係留策のバネ定数の影響

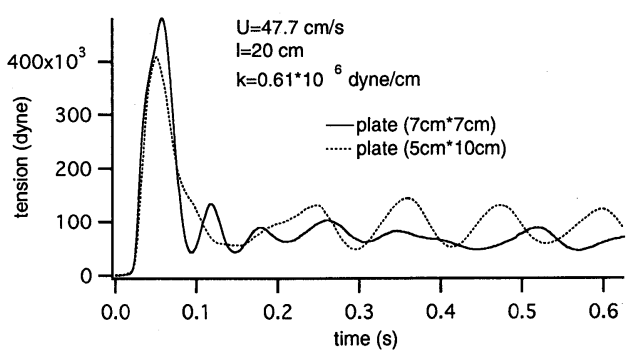

図一4 板の形状の違いによる張力の変化

る.

図一6 は，大きさの等しい板と膜について比較したも のである. 膜については, 衝撃力についても流速の 2 乗 に比例する傾向が現われており，板と異なった特性を示 している，また，定常力については，流速の大きい範囲 で膜の方が板よりも小さくなっているが，これは，流れ によって膜がしぼむことにより，実質的な受圧面積が減 少するためで，膜に及ぼす定常力の特徴である.

図一7 は, 膜のケースについて, 図-5 と同様にサイズ の影響をみたものである．膜が大きくなることにより， 
衝撃力には流速に線形的に変化する成分 が大きく現われてくるようになる，サイ ズによる違いは，流速が大きくなるにつ れて小さくなり，板の場合ほどサイズの 影響が顕著に現われないことがわかる。 定常力についても同様である.

\section{4. 衝撃張カの発生メカニズムに 関する考察}

\section{（1）衝撃張力のモデル化}

ここでは, 衝撃張力の発生メカニズム について考えるために，簡単な数学モデ ルを導入する．図一 8 に模式的に示すよ うに, バネ定数 $k$ の係留策の端部に取り 付けられた抵抗体を質点で置き変え，そ の質量を $m$ とする，係留策の伸び（抵抗 体の変位 $)$ を $x(t)$ と表すと, $x(t)$ に関す る微分方程式は，抵抗体の運動方程式よ り次式のように書くことができる.

$$
m \ddot{x}=-k x-M \ddot{x}+C_{d} \frac{1}{2} \rho A(U-\dot{x})^{2}
$$

ここにMは付加質量で，抵抗体の運動加 速度に比例する流体反力を表す。また， $U$ は流速, $C_{d}$ は抗力係数, $A$ は板の受圧 面積である. (1) 式は $N=C_{d}(1 / 2) \rho A$ と おくと，次のようにまとめられる。

$$
\ddot{x}-\frac{N}{m+M}(U-\dot{x})^{2}+\frac{k}{m+M} x=0
$$

この方程式は, $t=0$ で $\dot{x}=U$ なる初期条 件のもとに Runge-Kutta 法などで数值 的に解くことができる，ただし，抗力が 無視できる場合には，方程式は線形とな り, 解析解が得られる，このとき，係留 策の張力 $f$ は, $f=k x$ として次式で与え られる.これは，付加質量力のみによる 衝撃的な張力を表している.

$$
f=U \sqrt{k(m+M)} \sin (\sqrt{k /(m+M)} t)
$$

次に, 流体力を表す付加質量および抗力係数について 考える. 平板の付加質量についてはポテンシャル理論か ら求めることができるが，自由表面を有する流体中での 3 次元平板の運動については数值計算を用いる必要があ る．今回は，厳密ではないが，Meyerhoff (1970)が無限 流体中の 3 次元平板について求めた次式を用いた。ただ し，膜のように変形する物体に関する付加質量について
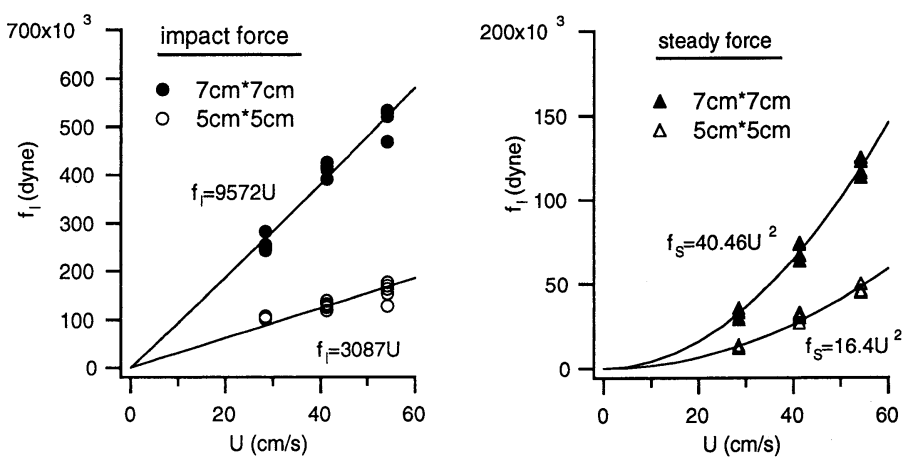

図一5 張力と流速の関係（1）一板のサイズの影響
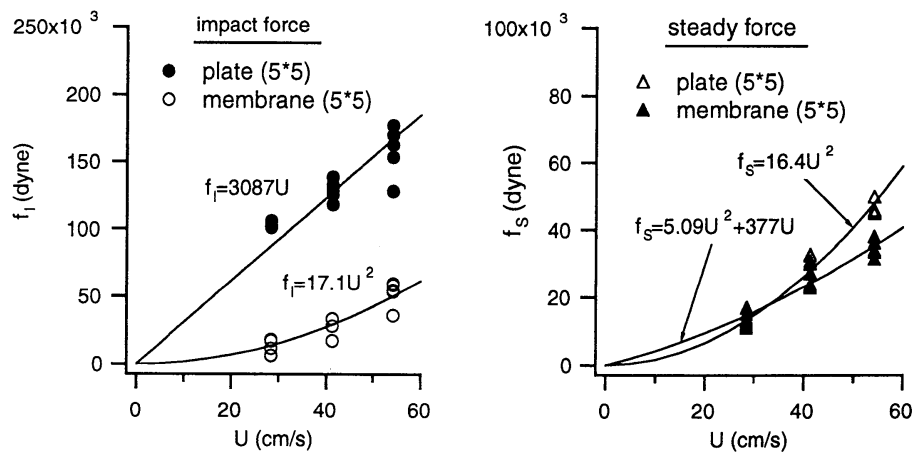

図一6 張力と流速の関係（2) 一板と膜の違い
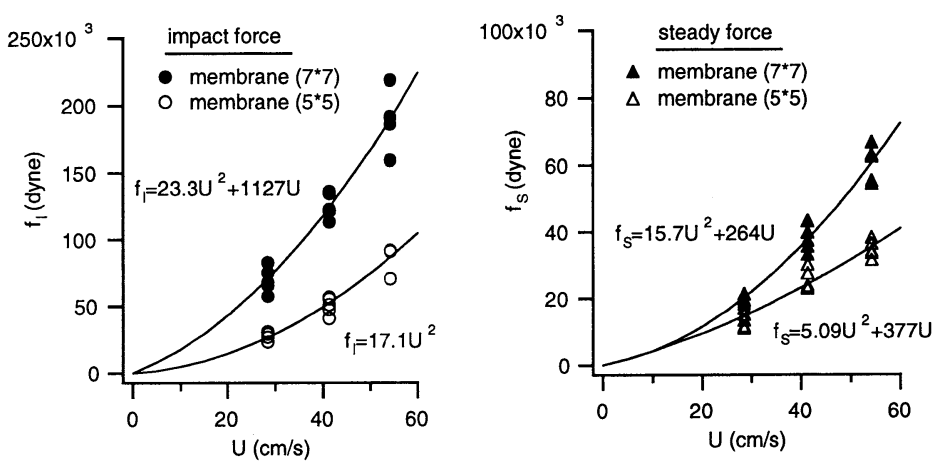

図一7 張力と流速の関係（3 ) 一膜のサイズの影響

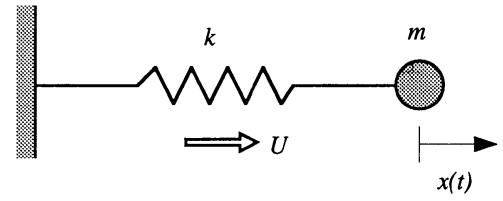

图一8バネ・質点系によるモデル化

は不明である。

$$
M=\alpha \cdot \rho \frac{\pi}{4} a^{2} b
$$


ここに, $a, b$ は板の一辺の長さで, $a$ が短軸方向長さ, $b$ が長軸方向長さである.また, $\alpha$ は板のアスペクト比に よって決まる係数で, $b / a=1$ のとき $0.579, b / a=2$ のと き $0.757, b / a=\infty て ゙ は 1$ で与えられる.もちろん, 自由 表面の存在は付加質量に影響を及ぼすが, 鉛直運動に比 べると水平運動に対する影響はあまり大きくない. 水面 直下で水平振動する喫水 $a$ の 2 次元平板については, Landweber and Macagno (1957) が求めており, $M=$ $2 \rho a^{2} \pi$ となる.これと, (4) 式で $\alpha=1, b=1$ とおいたも のとの比は, $8 / \pi^{2}=0.81$ となり, 自由表面の存在により付 加質量は 2 割程度小さくなることが予想される.ただし, 今回の計算では (4) 式の表現をそのまま用いた。一方, 抗力係数については, 定常力の実験結果から得られる值 を用いることとし，例えば $5 \mathrm{~cm} \times 5 \mathrm{~cm}$ の板については $C_{d}=1.31$, 膜については $C_{d}=1.0$ とした.

実験に用いた係留システムに対して，このモデルが適 用できるかどうかを確認するために，質量 $m$ の錘りを係 留策の先に取り付け, 空気中をある高さから落下させる ことにより, 衝撃張力を発生させる実験を行った。この 場合は外力として重力を考慮する代りに, 流体力が消去 できるので, 解析解が求められる. 図一9 は, 錘りの自由 落下による張力の時系列の実験值と理論值を比較した一 例であるが, 衝撃的な張力を, 大きさ, 立ち上がり時間 ともに正しく表現できていることがわかる.

次に,このモデルから予想される結果から, 先に述べ た実験結果の解釈を試みる. 図一 5 に示したように, 板の ケースでは衝撃力は流速にほほ比例することがわかっ た.一方，(3)式で与えられる付加質量力による張力も 流速に比例するので, 板の場合の衝撃力は付加質量力が 支配的であることが類推できる．ただし，正方形の板の 場合, $M \gg m$ とすると, $(3),(4)$ 式より $f$ の最大値は 板の一辺の長さの $3 / 2$ 乗に比例することになるが, 図一 5 より，実験では衝撃力に及ぼす板のサイズの影響が理論 より大きく現われていることがわかる．衝撃力に及ぼす バネ定数の影響についてみると, ( 3 ) 式より, 付加質量

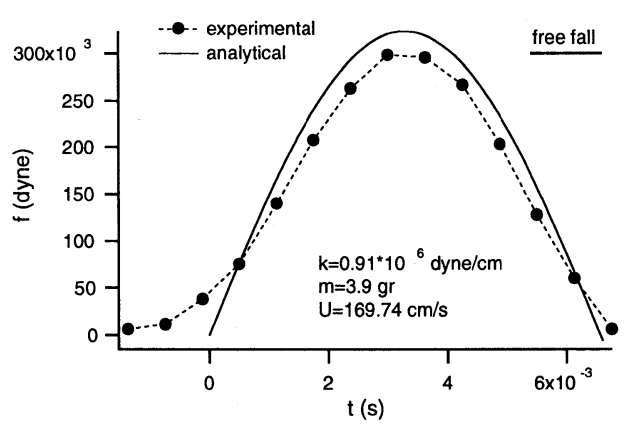

図一9 自由落下実験における実験值と計算値の比較
力はバネ定数の平方根に比例するので, 係留策が伸びや すいほど衝撃力は小さくなる.これは図一 3 から確認で きる. 一方, 膜のケースについては, 衝撃力にも流速の 2 乗に比例する成分がみられるが，これは膜では衝撃力 に及ぼす抗力の影響が板に比べて相対的に大きくなって いることを意味している。

\section{（2）実験とモデルの比較}

以上の様に，簡単な数学モデルで実験結果をある程度 定性的に説明できることがわかったが，ここでは具体的 に上記の数学モデルによる計算結果を実験結果と比較す ることにより，モデルの適用性とともに流体力の特性に ついて考察する. 図一10 は, 板および膜の実験結果と, モデルによる計算結果を比較したものである。 まず, 図 (a)の板のケースについてみると，（4）式で与えられる 付加質量および定常力から求めた抗力係数を用いた結果 (model) は, 張力のピーク值を過大に予測することがわ かる. また, 張力の立ち上がり時間が実験值よりもかな り短い.そこで, 付加質量を 0.4 倍に減少させた場合と抗 力係数を 0 にした場合について計算してみた. 付加質量 を減少させることにより, 衝撃力のピーク值は低減する ものの, ピークの立ち上がり時間が短くなり, 付加質量 力を低減するだけでは実験を説明できない. また，抗力 係数をゼロとしても, 衝撃力の波形はほとんど変化しな い. 以上より, 付加質量は理論值よりもかなり小さな值 をとることが予想されるが, 定数係数の流体力係数を用 いる限り, 実験值を時系列レベルで説明することは難し
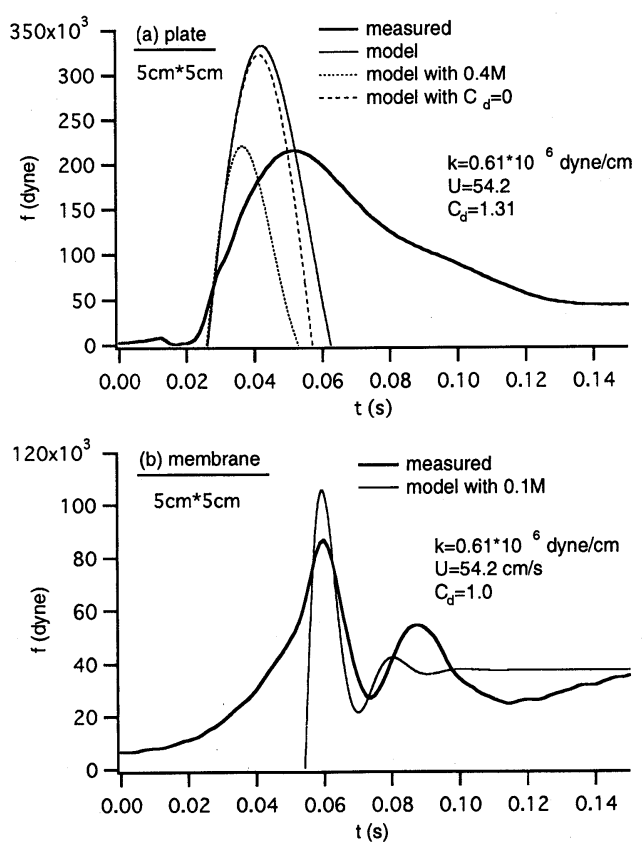

図-10 実験結果と計算結果の時系列の比較 
いことがわった．同様に，膜のケースについて比較した のが図(b)であるが,ここに示した計算值は, 付加質量を (4)式の値の $1 / 10$ としたものである.膜は緊張する際に 大きく変形するので，付加質量はかなり小さくなるもの と思われるが，ここでも張力のゆっくりした立ち上がり を説明できておらず，流体力係数が短時間のうちに大き く変化しているものと考えざるを得ない. ただし, 張力 がピークを示した後にみられる振動が計算でも再現され ているが，これは，質量がほとんど無視できる膜の場合 には,付加質量を考慮しない限り現われないものである.

\section{（3）係留策中の弾性波の伝播に関する検討}

上述のモデルでは，応力は係留策に静的に作用するも のとして取り扱ったが，衝揧的な張力を対象にする場合 には係留策中の応力の動的な伝播について考慮しておく 必要があろう．ただし，今回の実験条件についてはその 影響がないであろうことは，図一9の自由落下の実験と モデルの結果がよく合うことから確認できる.

一本の策の一端 (自由端) に作用する外力 $F(t)$ と, 他 端 (固定端) で生じる張力 $f(t)$ との関係は, 策中での減 衰を無視すると，次式で与えられる（例えば中川ら， 1976).

$$
f(t)=\frac{2}{l} \sqrt{\frac{E}{\rho_{c}}} \sum_{n=1}^{\infty}(-1)^{n+1} \int_{0}^{t} F(\tau) \sin \omega_{n}(t-\tau) d \tau
$$

ここに, $\rho_{c}, E$ は策の密度および弾性定数であり, $\omega_{n}=$ $(2 n-1) \pi \sqrt{E / \rho_{c}} / 2 l$ である.いま, 外力 $F(t)$ として, $F(t)$ $=F_{0} \sin p t(0 \leq t \leq \pi / p)$ 型のインパルスを与えるとき, $f / F$ の值は無次元数 $p l / \sqrt{E / \rho_{c}}$ のみの関数となる. 計算の 結果, この值が 0.1 程度までは $f(t)$ と $F(t)$ はほとんど 等しくなり, 弾性波の伝播の影響を考慮する必要がない ことがわかった. 今回の実験条件では, 高々 0.01 程度で あった，実際の膜体構造物の設計に抢いても，係留策の 応答は静的に考えても差し支えないものと思われる。

\section{6. あとがき}

本研究で取り扱った膜体構造物に発生する衝撃張力に 類似したものとして, パラシュートの開傘衝撃があり， Ludtke（1986）は，開豖衝撃に対する取り扱いを包括的 に示している.パラシュートの開金問題においては, 衝 撃力の発生は抗力のみが用いられており, パラシュート
の変形に伴う後流域の変化から説明されている. 本研究 では，付加質量力の影響を中心に調べたが，その結果以 下の上うな知見を得た。

（1）抵抗体が剛な平板の場合には, 衛揧張力は付加 質量力によって定性的に説明できるが, 張力の大きさや 立ち上がり時間を定量的に説明するためには, 流体力係 数の時間的な変化を導入する必要がある.

（2）抵抗体が変形する膜の場合や係留策が伸びやす い場合には，衝撃張力に及洣す付加質量力の影響は相対 的に小さくなり, 衝撃力に抗力成分を考慮する必要があ るが，付加質量を無視することはできない，

本研究を行うに当たり, 豊橋技術科学大学大学院生, 牧野友美君の協力を得た。また，関西空港 2 期工事にお ける污濁防止膜検討会における議論が有益であった。さ らに本研究を遂行する上で(株)ブリヂストンから研究費 の補助を受けた。ここに記して謝意を表する。

\section{参考文 献}

青木伸一・岡野 聡・椹木 亨 (1998)：自立式污㯰防止膜の有 効高さと係留力の実用算定法, 海岸工学諭文集, 第 45 巻, pp. 796-800.

安 成模・椹木 亨・青木伸一・萬藤 満 (1993)：波流れ共存 場に設置されたオイルフェンスに発生する衝擊展張力及び フェンスの挙動, 海岸工学椧文集, 第 40 巻, pp. 921-925.

椹木 亨・青木伸一・劉海波・山下 真 (1990): 波浪中に張 られた垂下式污㵋防止膜の展張ケーブルに発生する衝撃張 力の特性, 海洋開発論文集, vol. 6, pp. 311-316.

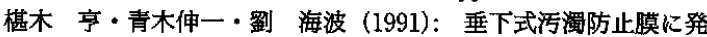
生する衝拲展張力のモデル化，海洋開発論文集，vol. 7, pp. 95-100.

田端竹千䅹 -八尋明彦 - 播本一正 - 相澤幹男 - 平石哲也 - 永松宏 一 (1999): 垂下式污濁防止膜の係留力に関する模型実験, 海岸工学論文集, 第 46 巻, pp. 846-850.

中川寈治・室津義定・岩董卓三 (1976): 工業振動学, 森北出版 $238 \mathrm{p}$.

Landweber, L. and M. C. de Macagno (1957): Added mass of two-dimensional forms oscillating in a free surface, Jour. of Ship Research, vol, 1, pp. 20-30.

Ludtke, W. P. (1986): Notes on a generic parachute opening force analysis, Collected Tech. Papers, AIAA 9th Aerodynamic Decelerator Balloon Tech. Conf., pp. 72-85.

Meyerhoff, W.K. (1970): Added masses of thin rectangular plates calculated from potential theory, Jour. of Ship Research, vol. 14, pp. 100-111.

Sawaragi, S, S. Aoki and H. Liu (1992): Wave-induced impulsive forces in tension cables of a floating silt curtain, Proc. 2nd Int. Offshore and Polar Eng. Conf., vol. III, pp. 339-346. 